\title{
Effect of Using Two Different Types of Engineered Nanomaterials on The Growth and Antioxidant Enzymes of French Bean Plants Hasaneen, M.N. A. ${ }^{1}$; Heba. M. M. Abdel-Aziz and Aya M. Omer Department of Botany, Faculty of Science, Mansoura University, Mansoura, Egypt 1e-mail: mohammednagib@mans.edu.eg
}

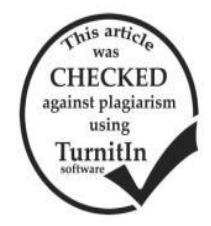

\section{ABSTRACT}

The application of nanomaterials in agriculture is one of the most greatly studied areas in nanotechnology as it includes the using of nanofertilizers to transport nutrient elements to the plant at the needed time and required amount, thereby improving the use efficiency. This work was designed to investigate the effects of soil incorporation of two different types of engineered nanofertilizer namely: carbon nanotubes and chitosan nanoparticles alone or loaded with nitrogen, phosphorus and potassium (NPK) on the different growth criteria of French bean plants. The results indicate that after about 30 days from the date of planting, nanomaterials either alone or in combination with NPK significantly decrease plant growth and increase the activity of antioxidant enzymes implying that French bean plants were exposed to an oxidative stress.

Keywords: carbon nanotubes, chitosan, French bean, nanofertilizer, antioxidant enzymes

\section{INTRODUCTION}

As nanotechnology is an interdisciplinary technology which solves problems and enters in all stages of production, processing, storing, packaging and transport of agricultural products, it is proved its place in agriculture and correlated industries (Froggett, 2009). Nanofertilizers are known as nutrient carriers with size ranging from 30 to $40 \mathrm{~nm}$ and due to their high surface area they are able to holding plentiful nutrient ions and release it slowly and gradually in a timely manner to a rhizospheric target that proportionate with crop demand and have high use efficiency. Nanofertilizers are ultrahigh absorption able to increase production, rise photosynthesis, and expansion of leaves surface area (INIC, 2014). Nanomaterials might be toxic than its bulk compound due to their superior contact surface area, especially in an agricultural ecosystem (Lang et al., 2011; Rizzello and Pompa, 2014).

Chitosan nanoparticles (nanochitosan) are one of the engineered nanomaterials generating from chitosan which is a linear hydrophilic polysaccharide that is biodegradable, biocompatible, non-toxic nature biopolymer and react with bioactive molecules due to the presence of $-\mathrm{NH}_{2}$ and $-\mathrm{OH}$ functional groups so, it has been used as a functional biopolymer in food and pharmaceutics (Dai et al., 2009; Hanafi, 2012; Cho et al., 2010). Chitosan nanoparticles $(\sim 78 \mathrm{~nm})$ that can be used for controlled release of NPK fertilizer sources such as urea, calcium phosphate and potassium chloride (Corradini et al., 2010). While, carbon nanotubes (CNTs) is six times lighter and hundred times stronger than stainless steel, as hard as diamond and its thermal capacity is twice that of pure diamond, their current carrying capacity is 1000 times higher than that of copper and thermally stable up to 4000 Kelven (Kumar, 2011). These physical and chemical properties enable carbon nanomaterials to be used in agriculture to increase the germination process, root growth, photosynthesis and crop yield (Flores et al., 2014). CNTs are used for the controlled release of nutrient, agrochemical, drug and biological delivery to specific cells of these reagents (Irin et al., 2012).

The aim of this work was to investigate the effects of soil incorporation of chitosan nanoparticles and carbon nanotubes loaded with NPK fertilizer at different concentrations on growth of French bean plants and their antioxidant enzymes.

\section{MATERIALS AND METHODS}

\section{Plant materials}

Pure strain of Phaseolus vulgaris cv. Contender seeds were kindly supplied by Horticultural Research Center, Ministry of Agriculture, Mansoura, Egypt.

2.Preparation and characterization of chitosan nanoparticles and carbon nanotubes loaded with NPK fertilizers

The chitosan poly-methacrylic acid (CS-PMAA) nanoparticles were obtained by polymerization of methacrylic acid (MAA) in chitosan (CS) solution in a two-step process according to De Moura et al. (2008) and Hasaneen et al. (2014). Meanwhile, CNTs easily and inexpensively prepared at room temperatures according to Lee and Seo (2011).

Incorporation of NPK into chitosan nanoparticles and carbon nanotubes was carried out according to Corradini et al. (2010) and Hasaneen et al. (2014).

\section{Time course experiments}

A large scale experiment, carried outdoor, normal day and light conditions, was designed so as to study the effect of four different levels of nanomaterials namely: CS-10, CS-100, CNTs- $20 \mu \mathrm{g} / 1$ and CNTs- $50 \mu \mathrm{g} / \mathrm{l}$ each level being used either alone or in combination with a recommended dose of each of $\mathrm{N}, \mathrm{P}$, and $\mathrm{K}$ attempted fertilizer. Thus, 45 pots, divided into nine groups (each of five pots) were used. One of these groups is left without treatments to serve as water control and the other 8 groups were separately treated with each of the 8 nanomaterial levels either alone or in combination with a recommended dose of each of $\mathrm{N}, \mathrm{P}$, and $\mathrm{K}$. Thus, a total of 9 treatments represented all planned possible applications of penta-replicated in a completely randomized design.

Uniformly- sized seeds of French bean (Phaseolus vulgaris cv. Contender) seeds were selected, washed thoroughly with tap water and then planted in a mixture of clay-loamy soil (2:1 v/v) in pots (30x 28x 26 $\mathrm{cm})$. The soil obtained from the Agriculture Research Station of Mansoura, Dakahlia Governorate, Egypt, was taken from the upper $30 \mathrm{~cm}$ arable layer. All pots contained equal amounts of homogenous soil $(8 \mathrm{~kg})$. The 
appropriate amount of nanofertilizers and the recommended dose for each of the NPK used were calculated and mixed with soil nanofertilizers before sowing. About 5 to 7 seeds were planted in each pot and given 16- days for germination in the soil. That was followed by thinning and only 5 seedling/ pots were left for experimentation.

All pots were irrigated with tap water every three days to maintain each of soil at the field capacity throughout the experiment. Samples were taken after 30 days from the date of planting. Sampling was made in a way so as to include all plants allotted for each treatment in the five pots

Experimental data were statistically analysis using one-way analysis of variance (ANOVA) with Post Hoc L.S.D. (least significant difference) test. * P value $<0.05$ was accepted statistically significant performed with statistical package for social science for windows (SPSS, version 13.0, 2004, Chicago, IL, USA).

\section{Estimation of antioxidant enzymes \\ Enzyme extraction}

Enzyme extracts were prepared by grinding 0.2 $\mathrm{g}$ of 30- d old fresh French bean leaves with $5 \mathrm{~cm}^{3}$ of chilled phosphate buffer, for determination of SOD, CAT, POX and GR activities. For SOD the extraction medium buffer was $0.1 \mathrm{M}$ phosphate buffer at $\mathrm{pH} 7.8$, while for CAT, POX and GR the extraction medium buffer was $0.1 \mathrm{M}$ phosphate buffer was at $\mathrm{pH} 6.8$. The mixture then was filtered through cheesecloth and the filtrate was centrifuged at $10000 \mathrm{rpm}$ for 20 minutes at $4^{\circ} \mathrm{C}$. The supernatant served as enzyme extract (Agarwal and Shaheen, 2007).

\section{Estimation of Superoxide Dismutase activity (SOD,} EC1.15.1.1)

The SOD activity was determined according to the method of Giannopolitis and Ries (1977). The reaction mixture was consisted of $0.1 \mathrm{~cm}^{3}$ of enzyme extract, $1 \mathrm{~cm}^{3}$ of working buffer $\left(10 \mathrm{~cm}^{3}\right.$ of phosphate buffer, $1 \mathrm{~cm}^{3}$ of nitro-blue-tetrazolium (NBT) and $1 \mathrm{~cm}^{3}$ of NADH) and mixed well. To initiate the reaction, 0.1 $\mathrm{cm}^{3}$ of phenazine methosulphate (PMS) was added. The absorbance was measured at $560 \mathrm{~nm}$.

\section{Estimation of catalase activity (CAT, EC1.11.1.6)}

A reaction mixture containing $1 \mathrm{~cm}^{3}$ of potassium phosphate buffer and $0.2 \mathrm{~cm}^{3}$ of $\mathrm{H}_{2} \mathrm{O}_{2}$ was add to $1.5 \mathrm{~cm}^{3}$ of plant extract to initiate the reaction and the activity was measured at $240 \mathrm{~nm}$ over $1 \mathrm{~min}$ by monitoring the removal of $\mathrm{H}_{2} \mathrm{O}_{2}$ (Gomes-Junior et al., 2007). CAT activity is expressed as $\mu \mathrm{mol} \mathrm{min} \mathrm{mg}^{-1} \mathrm{mg}^{-1}$ protein.

Estimation of Glutathione reductase activity (GR, EC1.8.1.7)

The method proposed by Beutler (1984) was adopted for assaying the activity of glutathione reductase. $1.5 \mathrm{~cm}^{3}$ of buffer was added to $0.5 \mathrm{~cm}^{3}$ of ethylene diamine tetra acetic acid (EDTA), $0.2 \mathrm{~cm}^{3}$ of oxidized glutathione (GSSG) and $0.1 \mathrm{~cm}^{3}$ of NADPH. To initiate the reaction, $0.2 \mathrm{~cm}^{3}$ of enzyme extract was added to the mixture. The enzyme activity is calculated intermediate of micromoles of NADPH oxidized /min/mg protein.
Estimation of Peroxidase activity (POX, EC1.11.1.7)

Peroxidase activity was assayed by the method of (Devi, 2002). $3 \mathrm{~cm}^{3}$ of pyrogallol buffer in $0.1 \mathrm{M}$ phosphate buffer was added to $0.1 \mathrm{~cm}^{3}$ of enzyme extract, and $0.5 \mathrm{~cm}^{3}$ of $1 \% \mathrm{H}_{2} \mathrm{O}_{2}$. The absorbance at 420 $\mathrm{nm}$ was read to determine the amount of formed purpurogallin. The enzyme activity was expressed in units. One unit is defined as unit per $g$ fresh weight per $\min$.

Estimation of polyphenoloxidase (PPO, EC. 1.10.3.1)

$1 \mathrm{~cm}^{3}$ of enzyme extract was added to $2 \mathrm{~cm}^{3}$ of phosphate buffer and $1 \mathrm{~cm}^{3}$ of Pyrogallol. The reaction mixture was incubated at $25^{\circ} \mathrm{C}$ for 1 minute, after that the reaction was stopped by the addition of $1 \mathrm{~cm}^{3}$ of 2.5 $\mathrm{N} \mathrm{H}_{2} \mathrm{SO}_{4}$. The absorbance of the formed purpurogallin was recorded at $420 \mathrm{~nm}$. The enzyme activity was expressed in units. One unit is defined as unit per $g$ fresh weight per minute. About $0.1 \mathrm{~cm}^{3}$ of the supernatant was added to $0.5 \mathrm{~cm}^{3}$ of phosphate buffer and $1 \mathrm{~cm}^{3}$ of 2,6-, dichlorophenyl indophenole (DCPIP). The absorbance was measured at $520 \mathrm{~nm}$ within $1 \mathrm{~h}$ (Devi, 2002).

\section{RESULTS AND DISCUSSION}

\section{Changes in growth parameters}

Root length, shoot length, fresh weight, dry weight, water content and leaf area were determined to evaluate the sequence of growth characters of the different treated plants. Treatment of French bean seeds or plants with either nanocomposite (nanochitosan NPK) or nanoengineered (carbon nanotubes NPK) fertilizers through soil incorporation technique led to significant progressive decrease in all growth parameters below the control values. The following sequence of treatments: control > CNTs-20 $\mu \mathrm{g} / \mathrm{L}>$ CNTs-NPK-20 $\mu \mathrm{g} / \mathrm{L}>$ CNTs-50 $\mu \mathrm{g} / \mathrm{L}>$ CNTs-NPK-50 $\mu \mathrm{g} / \mathrm{L}>\mathrm{CS}-10 \%>\mathrm{CS}-\mathrm{NPK}-10 \%>\mathrm{CS}-100 \%>\mathrm{CS}-\mathrm{NPK}-$ $100 \%$ was displayed with respect to French bean plants grown on clay-sandy soil and treated with soil incorporation technique throughout the entire period of the experiment (Table 1 and figure 1).

In particular, the use of nanomaterials for improving plant growth, generally related to the concentrations of nanoparticle applied to various plant organs or tissues (Khodakovskaya et al., 2009). Generally, nanoparticles may be applied to seeds or roots. But the interactions between nanoparticles, soil and plants may be complicated and cause ecological safety problems (Wang et al., 2013). Furthermore, soil application of nanomaterials at low concentration can enhance growth of plants while nanomaterilas applied through nutrient solution increase the bioavailability and accumulation in plants thereby inhibiting growth (Razzaq et al., 2016). Nanoparticles toxicity depends on the differences in root anatomy because xylem structures determine the speed of water transport and different xylem structures may demonstrate different uptake kinetics of nanoparticles (Lee et al., 2010). 
Table 1: The effects of soil incorporation technique of nanocomposite (chitosan nano NPK) and nanoengineered (carbon nanotubes NPK) fertilizers on the growth of 30 - $d$ old French bean plants (vegetative stage). *Mean values listed are significant different from control at $p \leq 0.05$

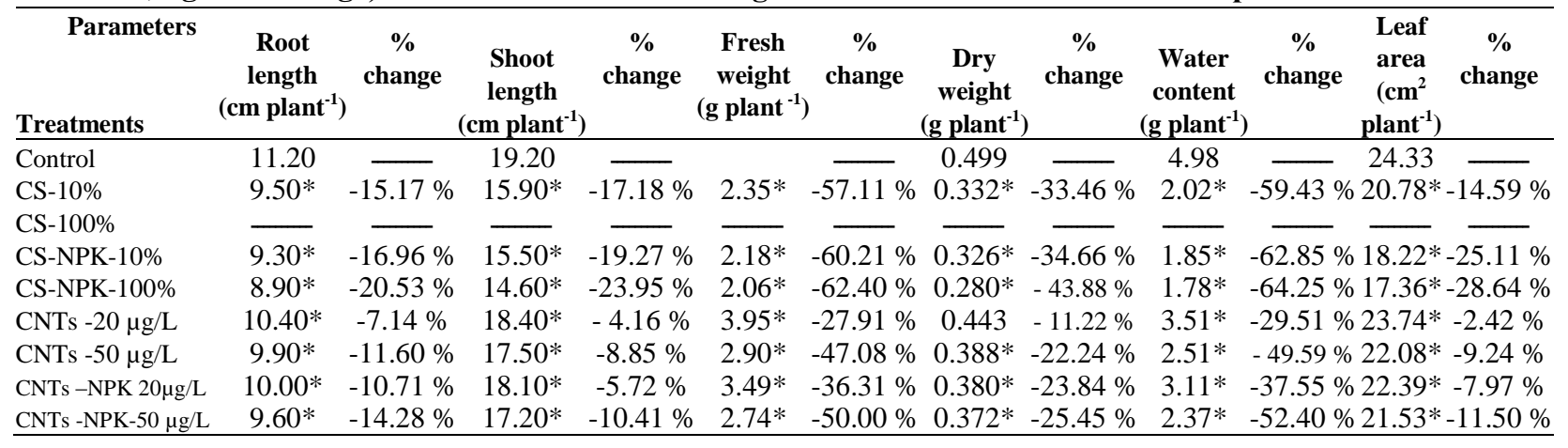
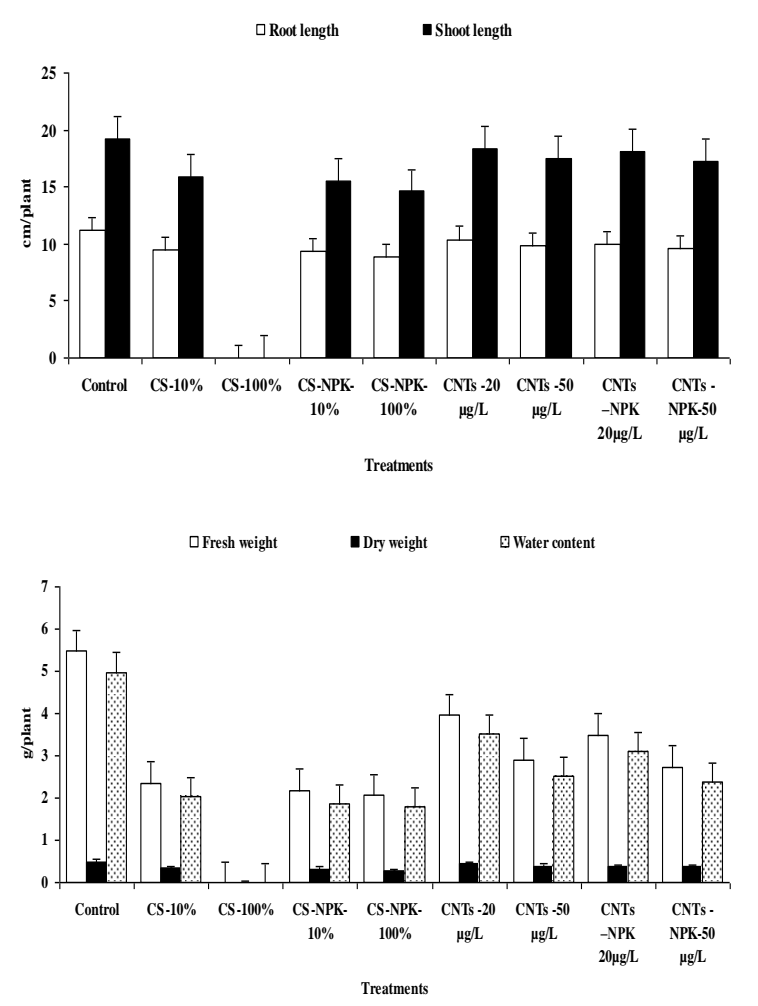

\section{Changes in enzymatic antioxidants}

Tables 2 and figures 2 show the activity of SOD, POX, PPO, GR and CAT enzymes of the control as well as the differently treated French bean plants with soil incorporation technique. In the variously treated plants, there appeared a progressive increase in all the activities of the determined enzymes throughout the duration of the experimental 30- day- period. The following sequence of treatments in variously treated plants: Control $<$ CNTs- $20 \mu \mathrm{g} / \mathrm{L}<\mathrm{CNTs}-\mathrm{NPK}-20 \mu \mathrm{g} / \mathrm{L}<\mathrm{CNTs}$ $-50 \mu \mathrm{g} / \mathrm{L}<\mathrm{CNTs}-\mathrm{NPK}-50 \mu \mathrm{g} / \mathrm{L}<\mathrm{CS}-10 \%<\mathrm{CS}-\mathrm{NPK}-$ $10 \%<$ CS-100 \%<CS-NPK-100\% was displayed with respect to SOD, POX, PPO, GR and CAT activities of French bean plants treated with soil incorporation technique.

The percentage of improvement in SOD, POX, PPO, GR and CAT activities of French bean plants treated with soil incorporation technique were shown in table 2. For example in French bean plants treated with CNTs- $20 \mu \mathrm{g} / \mathrm{L}$ were found to be: $13.58 \%, 4.33 \%$, $15.00 \%, 1.61 \%$ and $11.91 \%$ and in French bean plants treated with CS-NPK-100 \% were: $25.54 \%, 64.00 \%$, $16.00 \%, 15.90 \%$ and $46.18 \%$ respectively.

After entering the cell, nanoparticles may induce intracellular oxidative stress which represents a common mechanism for cell damage induced by nanoparticles (Pulskamp et al., 2007) by disturbing the balance between both oxidant and antioxidant processes and generating harmful ROS due to their large surface areas. Excessive oxidative stress may also alter membranes, lipids, proteins and nucleic acids, which stimulates the antioxidant defense system resulting in cellular injury or leads to cell death (Moore, 2006; Laware and Raskar, 2014). The response of plant to nanoparticles stress has been evaluated in various crops at physiological and biochemical levels (Hossain et al., 2015).

Our results are in agreement with Tan et al. (2009) observation since antioxidant enzymes in in rice cells were significantly induced when treated with 20 $\mathrm{mg} / \mathrm{L}$ of MWCNTs. This enzyme contents increment indicates that the cells are under oxidative stress and it may lead to cell proliferation decrease or cell death through the apoptotic pathway or necrosis. Tea leaves treated chitosan nanoparticles showed significant increase in accumulation of POX, PPO, SOD, CAT and 
phenol content. In chitosan nanoparticles treated leaves, both enzyme activity and mRNA expression levels of CAT and SOD were found to be significantly higher than control plants. Hence, the increased expression of SOD and CAT might protect the plants from the oxidative stress (Chandra et al., 2015).

Due to mechanical stress and injury, plants change their morphology or growth rate to adapt to stress. This phenomenon has known as thigmomorphogenesis. Also plant hormones play an important role in this process (Chehab et al., 2009) as the activity of jasmonic acid, the plants stress hormone, increases, while, the activity of auxin, morphogenesis and plant growth hormone decreases. This alteration in plant hormone levels may be associated with the increase of peroxidase activity (Woodward and Bartel, 2005) and this increase is accompanied with the oxidative stress caused by nanomaterials and initiates the mechanism of response of the plant to stress.

Table 2: Effect of soil incorporation of nanocomposite (chitosan nano NPK) and nanoengineered (carbon nanotubes NPK) fertilizers on the activities of antioxidant enzymes (SOD; U/g fresh weight, POX; U/g fresh weight/ min, PPO; U/g fresh weight/ min, GR; U/g fresh weight, CAT; U/g fresh weight) of 30- d old French bean plants. *Mean values listed are significant different from control at $p \leq 0.05$

\begin{tabular}{|c|c|c|c|c|c|c|c|c|c|c|}
\hline Par & SOD & $\begin{array}{c}\% \\
\text { changes }\end{array}$ & OX & $\begin{array}{c}\% \\
\text { changes }\end{array}$ & PPO & $\begin{array}{c}\% \\
\text { changes }\end{array}$ & GR & $\begin{array}{c}\% \\
\text { changes }\end{array}$ & CAT & $\begin{array}{c}\% \\
\text { changes }\end{array}$ \\
\hline & & & & & & & & & & \\
\hline & $7 *$ & or 1 & $.11 *$ & $\begin{array}{c}37.00 \% \\
\end{array}$ & $1.16^{*}$ & $\%$ & & & & \\
\hline & & & $45 *$ & & $16^{*}$ & & 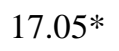 & & $7.42 *$ & \\
\hline & $*$ & & $4.92 *$ & & & & $*$ & & & \\
\hline- & $*$ & & $3.13^{*}$ & & * & & $*$ & & $6.01 *$ & \\
\hline & $37 *$ & & $3.80 *$ & & & & & & & \\
\hline & & & & & & & & & & \\
\hline NT -NPK- & $16.80^{*}$ & $18.89 \%$ & $3.87 *$ & $29.00 \%$ & $1.14 *$ & $14.00 \%$ & $16.37^{*}$ & $10.30 \%$ & $7.28 *$ & $35.56 \%$ \\
\hline
\end{tabular}

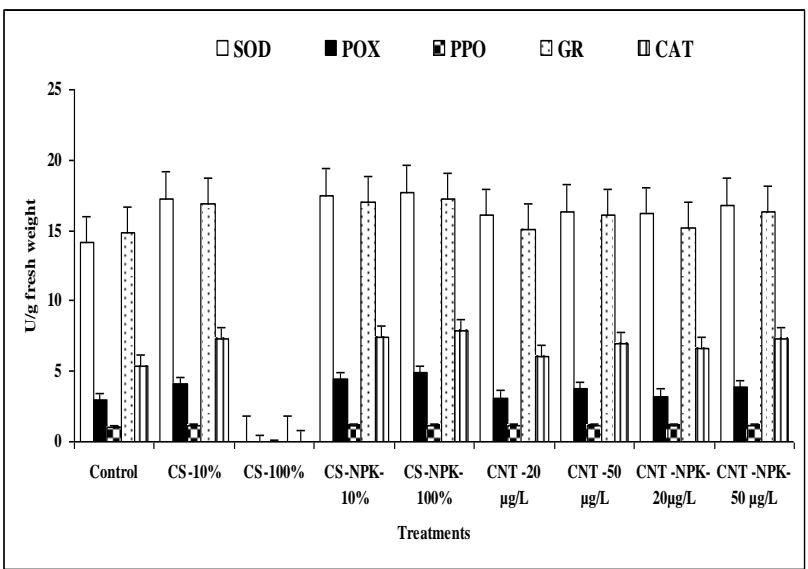

Fig. 2. Effect of nanocomposite (chitosan nano NPK) and nanoengineered (carbon nanotubes NPK) fertilizers on antioxidant enzymes of 30- d old French bean plants treated by soil incorporation. Vertical bars represent the standard error $( \pm$ S.E. $)$.

\section{REFERENCES}

Agarwal, S. and Shaheen, R. (2007): Stimulation of antioxidant system and lipid peroxidation by abiotic stresses in leaves of Momordica charantia. Brazilian J. Plant Physiol.,19:149-161.

Beutler, E. (1984): Red cell metabolism. In: A manual of biochemical methods. 3rd ed. Grune and Starton, Inc. Orlando, FL 32887, London.

Chandra, S., Chakraborty, N., Dasgupta, A., Sarkar, J., Panda, K. and Acharya, K. (2015): Chitosan nanoparticles: A positive modulator of innate immune responses in plants. Sci. Rep., 5: 15195.
Chehab, E.W., Eich, E. and Braam, J. (2009): Thigmomorphogenesis: a complex plant response to mechano-stimulation. J. Exp. Bot., 60: 43-56.

Cho, Y., Shi, R. and Borgens, B.R. (2010): Chitosan produces potent neuroprotection and physiological recovery following traumatic spinal cord injury. J. Exp. Biol., 213: 1513-1520.

Corradini, E., De Moura, M.R. and Mattoso, L.H.C. (2010): A preliminary study of the incorporation of NPK fertilizer into chitosan nanoparticles. Express Polymer Lett., 4: 509-515.

Dai, M., Zheng, X., Xu, X., Kong, Y.X., Guo, G., Luo, F., Zhao, X., Wei, Q.Y. and Qin, Z. (2009): Chitosan alginate sponge: preparation and application in curcumin delivery for dermal wound healing in rat. J. Biomed. Biotechnol., Article ID 595126, 8 pages.

DeMoura, M.R., Aouda, F.A. and Mattoso, L.H.C. (2008): Preparation of chitosan nanoparticles using methacrylic acid. J. Colloid Interface Sci., 321:477- 483.

Devi, P. (2002): Principles and methods in plant molecular biology, biochemistry and genetics, $1^{\text {st }}$ edition, Agrobios, India.

Flores, D., Chacón, R., Alvarado, L., Schmidt, A., Alvarado, C. and Chaves, J. (2014): Effect of using two different types of carbon nanotubes for blackberry (Rubus adenotrichos) in vitro plant rooting, growth and histology. Ameri. J. Plant Sci., 5: 3510-3518. 
Froggett, S. (2009): Nanotechnology and agricultural trade. OECD Conference on the Potential Environmental Benefits of Nanotechnology: Fostering Safe Innovation-Led Growth.

Giannopolitis, C.N. and Ries, S.K. (1977): Superoxide dismutases occurrence in higher plants. Plant Physiol., 59: 309- 314.

Gomes-Júnior, R.A., Gratão, P.L., Gaziola, S.A., Mazzafera, P., Lea, P.J. and Azevedo, R.A. (2007): Selenium-induced oxidative stress in coffee cell suspension cultures. Funct. Plant Biol., 34: 449-456.

Hanafi, N. (2012): Role of chitosan nanoparticles in targeting Ehrlich tumor cells transplanted in albino mice. Inter. J. Res. Biol. Sci., 2: 6-17.

Hasaneen, M.N.A., Abdel-Aziz, H.M.M., El-Bialy, D.M.A. and Omer, A.M. (2014): Preparation of chitosan nanoparticles for loading with NPK. Afric. J. Biotechnol., 13: 3158-3164.

Hossain, Z., Mustafa, G. and Komatsu, S. (2015): Plant responses to nanoparticle stress. Int. J. Mol. Sci., 16: 26644- 26653.

INIC, (2014): Iran Nanotechnology Initiative Council. First nano-organic iron chelated fertilizer invented in Iran. http://www.iranreview. org/content/Documents/Iranians_Researchers_Pr oduce_Nano_Organic_Fertilizer.htm.

Irin, F., Shrestha, B., Canas, J.E., Saed, M. A. and Green, M. J. (2012): Detection of carbon nanotubes in biological samples through microwave-induced heating. Carbon. 50: 44414449.

Khodakovskaya, M., Dervishi, E., Mahmood, M., Xu, Y., Li, Z., Watanabe, F. and Biris, A.S. (2009): Carbon nanotubes are able to penetrate plant seed coat and dramatically affect seed germination and plant growth. ACS Nano., 3: 3221-3227.

Kumar, M. (2011): Carbon nanotubes synthesis and growth mechanism. In: Carbon nanotubes synthesis, characterization, applications, (ed. Yellampalli, S.), ISBN: 978-953-307-497-9, In Tech, http://www.intechopen.com/books/carbonnanotubes synthesis.
Lang, X., Hirata, A., Fujita, T. and Chen, M. (2011): Nanoporous metal/oxide hybrid electrodes for electrochemical supercapacitors. Nat. Nanotechnol., 6: 232-236.

Laware, S.L. and Raskar, S. (2014): Effect of titanium dioxide nanoparticles on hydrolytic and antioxidant enzymes during seed germination in onion. Int. J. Curr. Microbiol. App. Sci., 3: 749760

Lee, C.W., Mahendra, S., Zodrow, K., Li, D., Tsai, Y.C., Braam, J. and Alvarez, P.J.J. (2010): Developmental phytotoxicity of metal oxide nanoparticles to Arabidopsis thaliana. Environ. Toxicol. Chem., 29: 669- 675.

Lee, D.W. and Seo, J.W. (2011): Preparation of carbon nanotubes from graphite powder at room temperature._http://arxiv.org/pdf/1007.1062.

Moore, M.N. (2006): Do nanoparticles present ecotoxicological risks for the health of the aquatic environment?. Environ. Int., 32: 967- 976.

Pulskamp, K., Diabaté, S. and Krug, H.F. (2007): Carbon nanotubes show no sign of acute toxicity but induce intracellular reactive oxygen species in dependence on contaminants. Toxicol. Lett., 168: $58-74$.

Razzaq, A., Ammara, R., Jhanzab, H.M., Mahmood, T., Hafeez, A. and Hussain, S. (2016): A novel nanomaterial to enhance growth and yield of wheat. Nanosci. Techol., 2: 55- 58.

Rizzello, L. and Pompa, P.P. (2014): Nanosilver-based antibacterial drugs and devices: mechanisms, methodological drawbacks, and guidelines. Chemi. Soci. Rev., 43:1501-1518.

Tan, X., Lin, C. and Fugetsu, B. (2009): Studies on toxicity of multiwalled carbon nanotubes on suspension rice cells. Carbon. 45: 3479-3487.

Wang, W., Tarafdar, J.C. and Biswas, P. (2013): Nanoparticle synthesis and delivery by an aerosol route for watermelon plant foliar uptake. J. Nanopart. Res., 15: 1415-1417.

Woodward, A.W. and Bartel, B. (2005): Auxin: regulation, action, and interaction. Ann. Bot., 95: 707-735.

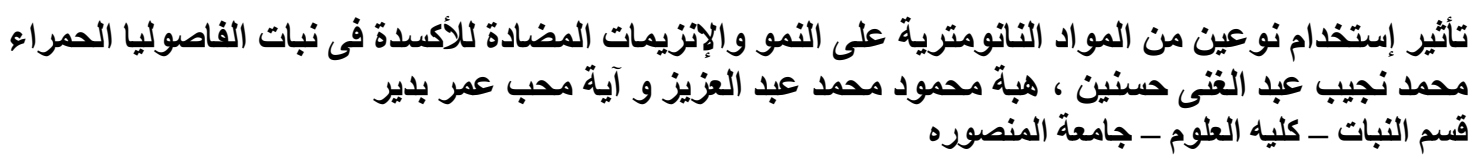

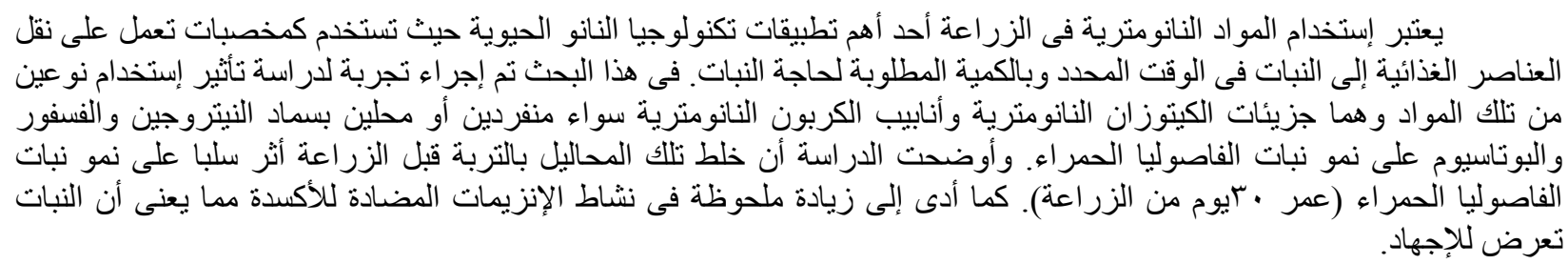

